\title{
Employment Problem Analysis Embodied in the Higher Vocational Students' Employment Difficult
}

\author{
Juan $\mathrm{He}$ \\ Hunan Mass Media Vocational Technical College, Changsha, 410100, China
}

Keywords: Higher vocational education; Graduate; Employability

\begin{abstract}
Our country's higher vocational education has developed rapidly in recent years. Along with the education scale expanding, higher vocational graduates increase rapidly, higher vocational students' employment problem cannot allow to ignore. This article from the reasons of higher vocational college students employment difficulty, based on the overall employment situation, society, enterprise employment system, the current higher vocational education teaching mode and several levels abilities of the students themselves were analyzed, and the force to explore how to improve higher vocational students' employment, fundamentally solve the problem of the current higher vocational education in the face of difficult employment.
\end{abstract}

\section{Introduction}

In recent years, under the country advocates, higher vocational education had great development; it has become a part of higher education. Higher vocational graduates is rising year by year, resulting in the higher vocational students' employment problem in the development of higher vocational education, especially the phenomenon of "talent high consumption", the problem of higher vocational graduates' employment is becoming worse and worse. Higher vocational graduates as a good group of labor resources in our country, the timely and reasonable full employment to social stability and economic development plays a decisive role and significance. The employment measures to that end, countries so as to improve higher vocational graduates employment environment; Schools to develop a variety of channels, expanding employment information, improving the employment guidance system, guide students actively carry out career planning and design; Students have to establish correct greatly, increase knowledge and ability reserve, improve employment.

\section{The meaning of employment force}

Labor force, it is to point to get initial employment, maintain employment and the ability to get new jobs when necessary. Simply it is to obtain employment force and the ability to continue to finish the work, namely "comprehensive professional ability". For higher vocational students, employment force depends on it has the knowledge, skills and attitudes, it includes both technical operation ability, technology, management ability, technical diagnosis ability and the ability to repair and other professional, also including cognitive ability, expression ability, social ability, survival ability and general ability, it also includes the professional dedication, cooperation ability, which will quality and psychological health, etc. In today's knowledge economy era, the informationization and globalization development trend of higher education students raised higher labor force requirement. Concept of labor force is reflected the different requirements of the times, it both requires solid knowledge, pay more attention to ability of comprehensive development of higher education graduates.

\section{The causes analysis of difficult employment of higher vocational students}

\section{Overall employment situation is not optimistic}

Education minister Yuan Guiren indicated in 2010 the national ordinary university graduates work video conference said that: the negative impact of the international financial crisis on China's 
employment has not been eliminated; the macro employment situation is still grim, as graduate students in high vocational school college graduates is in a relatively weak group, faces enormous pressure on employment.

Social barriers to gradually into the higher vocational students' employment discrimination

Employment discrimination is a social unit of choose and employ persons are unfair and unreasonable when recruiters to different degree and gender of applicants. In the talent market, employment discrimination phenomenon abound, such as gender, age, household register discrimination, even appear serious talent high consumption phenomenon, namely the degree of the supremacy, the first condition of higher education to become talents.

\section{Enterprise employment system is not reasonable}

Some unreasonable system of enterprise of choose and employ persons, in the pursuit of practical and low cost, applicants have rich work experience, hot loyal to directly employ familiar with business, it can be directly employed staff, at the beginning the ability is poor, it needs take training cost, stability is not high barriers refused to graduates by setting work experience.

\section{Setting dislocation of college education of professional}

The training goal of higher vocational education should be aimed at different career or professional post (group) training for production, management, service the first line of advanced applied technological talents. And some schools still according to the traditional exam-oriented education teaching, heavy theory, light practice, cultivate the students' operation ability is generally poor; And even individual school opened professional teachers according to their own situation, regardless of the talent market demand.

\section{The hardware environment of higher vocational education needs to be perfected}

To meet the needs of higher vocational professional teachers and practice training conditions is the most key hardware environment of higher vocational education. Higher vocational teachers should not only have solid professional theory knowledge, but also skilled operate, technology application ability. Many teachers in higher vocational colleges, only stay in this professional academic theory research, not actively lead the students to carry out the practice exercise, it is hard to meet the requirements of higher vocational education skills training for students. Coupled with the government's investment in higher vocational colleges, the original practice training conditions leads to the students' practical training link, it is difficult to keep up with, the students master the practical skills could not reach the requirements of modern enterprise of skilled talents.

\section{The reason of the students own}

Students with unit of choose and employ persons the cognition of "the most important ability". According to the concerned investigation shows, hire when unit of choose and employ persons in the eyes of students' ability is mainly study, mental status and the vocational comprehensive ability. One is in terms of learning situation, unit of choose and employ persons is the requirement of the students for employment, in addition to academic performance, more weight is given to students practical application ability of knowledge; In the survey of higher vocational students, more students think that the most important, it is also by China's contemporary education teaching mode of higher vocational schools. Thus it can be seen that unit of choose and employ persons and students two main different demands on the student's ability. Second, in the spiritual, enterprise of choose and employ persons wants students to have certain moral tutelage, has the team cooperation spirit, has the sense of responsibility, psychological health, etc. After students employment can as early as possible into the role, enterprise culture, building a harmonious team, to make its own contribution to the development for the enterprise. More students through participating in the school or community work to improve and shape personal qualities and related ability, accordingly, but students' group co., LTD., turnout is restricted, student participation motives are different, leading to a lot of time to participate in the crowd and at the end of the expected purpose and effect. Three is comprehensive ability, including the students' learning ability, problem-solving ability, and innovation spirit and strain capacity. The four abilities by unit of choose and employ persons is the most significance. Because of its direct relation to whether the students can adapt to the new work environment as soon as possible, and constantly create new value for the enterprise. Therefore, higher vocational schools in the daily 
teaching should focus on cultivating students' ability to solve the problem, as one of the primary goals of talent training, not only to give students the knowledge, more important is to cultivate the practice ability.

Above all, all is the cause of higher vocational students' employment, visible, to fundamentally solve the problem of the current difficult employment of higher vocational education are facing, it must depend on society, school and individual tripartite joint effort, especially individual students and how to improve their labor force, timely, reasonable employment, become a top priority.

\section{How to improve vocational students' employment}

\section{Increase the intensity of government regulation, mechanism of innovation education}

Government should intensify education regulation, in view of the influence of the disadvantage of higher vocational students' employment, construct the market demand oriented education mechanism, established comply with national, regional industrial structure adjustment and market economy development needs, cultivate applied and practice operational skills talents.

\section{School education is making teaching reform, so as to adapt to market changes}

Schools have to develop a variety of channels, expanding employment information. Improving the employment guidance system, guide students actively carry out career planning and design. The training goal of higher vocational education is training for the production, management, service the first line of advanced applicable technology talented person, like enterprise production product, it is in line with the market demand, that is very important. Therefore, higher vocational colleges to analyze the market demand for talents, science forecast, take the market as the starting point, with the employment as the guidance, adjust the professional education content, to ensure that training talents "marketable". Outside the professional theory knowledge, we should not only pay attention to a professor of higher vocational teachers, but also pay attention to the cultivation of practice ability, encourage students to participate in relevant professional social practice more, learn more about related profession present situation, growth experience.

To establish and improve graduates employment information network, we should open up various channels of employment, for the employment of higher vocational graduates to provide timely and accurate information. Universities can through the establishment of practice base, employment related enterprise managers as a guiding teacher, conducting seminars and other forms of unit of choose and employ persons, strengthen the relationship with the enterprise. At present, some higher vocational colleges and social enterprise cooperation, for students to carry out the talents train, this model is worth promoting. To establish a perfect career guidance system, guide the students in vocational college actively carry out career planning and design. Employment guidance work to the combination of phases and continuity is very important. Continuity or centralized employment guidance, stage is different according to different stages to give personalized guidance. College basic courses in the employment guidance, and often is for seniors, the provisional education of graduates is not enough to cope with the challenges of the employment situation. Therefore should be started, at the beginning of the higher vocational students enrolled according to different age stages of development, personality characteristics, to give students career guidance, positive and effective planning their careers.

\section{Students should establish correct greatly, increase knowledge and ability}

The first is to change the view of "a choice for life" seting up the dynamic view of "life". With the development of social economy, occupational mobility is more frequent, two-way choice, independent choosing profession, occupation flow gradually attract people's attention. Employees can accord to their own interests, career development space to choosing a career. "A choice for life" view is gradually replaced by the dynamic view. Higher vocational graduates can lower appropriately choosing standard, set up "employment first, selection, and entrepreneurship" correct greatly.

Again is to participate in social practice activities, more up stocks of knowledge and ability, promote employment ability. Higher vocational education is a professional education, in order to develop professional competence of the talents, higher vocational colleges carefully constructed the 
corresponding course system and education teaching plan. Professional knowledge is the basis of employment, if specialized knowledge not firm, it is not only unable to guide relevant professional practice activities, but also let alone work related. Stage at school, students must learn and master the professional knowledge in the first place, only to master the basic professional knowledge and professional skills; it can more effectively guide the relevant professional practice.

The training goal of higher vocational education is for different professional or professional positions (group) training for production, management, service the first line of advanced applied technological talents. Therefore, besides what we must know the professional knowledge of the system, enterprise of choosing and employ persons more weight is given to the students' ability of practical operation. Higher vocational students should make full use of the school to provide all kinds of practice platform by taking an active part in all kinds of student organizations, widely participate in social practice activities, efforts to improve their practical ability, improve employment.

\section{Higher vocational students should conscientiously strengthen the suffering consciousness, consciously improve their own quality}

Higher vocational students' employment is an objective phenomenon, but they are not disadvantaged groups. In the job market, there are also cultural. They have knowledge, skills, the strong competition ability of the crowd. Labor force is important for personal survival ability, higher vocational students can timely and reasonable employment, the decision is to individual students, and it should not be simply put the blame on the government and the society. Higher vocational students should face up to reality, and constantly strengthen the suffering consciousness, consciously to raise their comprehensive quality. On the one hand, make good use of the school learning time, extensive hunting knowledge, exercising the employment ability, grasp the key employment; Reasonable career planning, on the other hand, realize self, character, innovation ideas, set up the correct choosing profession idea, reserve energy for future employment.

To sum up, vocational students' employment difficulty is regional and structural, society, schools and students are objective and treat calmly, three-way joint efforts. Solve the employment problem, the key factors to enhance the student's own labor force. Therefore, higher vocational colleges should help students set up correct concept of employment, to improve the employment guidance system; guide students actively carry out career planning and design. Higher vocational students will take an active part in student organization, participate in social practice activities, and take the initiative to take part in social work, to exercise their various aspects ability, improve employment. With the rapid development of our country's economy, the deepening of the education teaching reform in higher vocational colleges, gradually perfect the employment system, the higher vocational students' employment situation is bound to have a big change.

\section{References}

[1] Zhang Hugui. Solve the difficult employment of college students is the key to improve the employment force. Journal of Literature and History expo (theory). 2009 (3).

[2] Li Zheng. Research of contemporary university students' employment problems. Journal of Guang Dong Youth Cadre Institute. 2007 (01).

[3] Zhang Wan juan. Introduction to college students' employment and the strategy. Journal of science and education Wen Hui (paper of beginning ten days of a month). 2011 (9).

[4] Zhou Qian. Analyses the contemporary university students' employment in our country. Science and technology to become rich. 2010 (21).

[5] Cao Juhua. The perspective of harmonious campus in university students' employment. Journal of WuHan University of Engineering, 2009 (10). 